\title{
Interfamilial relationships in order Fabales: new insights from the nuclear regions sqd1 and 265 rDNA
}

Article

Accepted Version

Aygoren Uluer, D., Hawkins, J. A. and Forest, F. (2020) Interfamilial relationships in order Fabales: new insights from the nuclear regions sqd1 and 26S rDNA. Plant Systematics and Evolution, 306 (4). 66. ISSN 0378-2697 doi: https://doi.org/10.1007/s00606-020-01691-7 Available at https://centaur.reading.ac.uk/91703/

It is advisable to refer to the publisher's version if you intend to cite from the work. See Guidance on citing.

Published version at: http://dx.doi.org/10.1007/s00606-020-01691-7

To link to this article DOI: http://dx.doi.org/10.1007/s00606-020-01691-7

All outputs in CentAUR are protected by Intellectual Property Rights law, including copyright law. Copyright and IPR is retained by the creators or other copyright holders. Terms and conditions for use of this material are defined in the End User Agreement.

www.reading.ac.uk/centaur 
Central Archive at the University of Reading

Reading's research outputs online 
AYGOREN ULUER ET AL.: INTERFAMILIAL RELATIONSHIPS IN ORDER FABALES: NEW INSIGHTS FROM

THE NUCLEAR REGIONS sqd1 AND 26S rDNA

INTERFAMILIAL RELATIONSHIPS IN ORDER FABALES: NEW INSIGHTS FROM THE NUCLEAR REGIONS sqd1 AND 26S rDNA

Deniz Aygoren Uluer ${ }^{1,4}$, Julie A. Hawkins ${ }^{2}$, Félix Forest ${ }^{3}$

${ }^{1,4}$ Ahi Evran University, Cicekdagi Vocational College, Department of Plant and Animal Production, Boyalik Mahallesi, Stadyum Caddesi, Turan Sok. No:18. 40700 Cicekdagi, Kirsehir, Turkey, d.aygoren@ahievran.edu.tr

${ }^{2}$ School of Biological Sciences, Lyle Building, University of Reading, Whiteknights, Reading, Berkshire, RG6 6BX, United Kingdom, j.a.hawkins@reading.ac.uk

${ }^{3}$ Royal Botanic Gardens, Kew, Richmond, Surrey, TW9 3DS, United Kingdom, F.Forest@kew.org

${ }^{4}$ Author for correspondence: Deniz Aygoren Uluer, Ahi Evran University, Cicekdagi Vocational College, Department of Plant and Animal Production, Boyalık Mahallesi, Stadyum Caddesi, Turan Sok. No:18 40700 Cicekdagi, Kirşehir, Turkey, email: d.aygoren@ahievran.edu.tr, Work phone: +903862805500, Fax: +903862805528 . 


\section{ABSTRACT}

Leguminosae, Polygalaceae, Quillajaceae and Surianaceae together comprise the order Fabales. Phylogenetic relationships within Fabales remains an unsolved problem even though interfamilial relationships have been examined in a number of studies using different sampling approaches and both molecular and morphological data. In this study, we gather information from the nuclear $26 \mathrm{~S}$ rDNA region as well as previously published data from the sqd1, matK and $r b c \mathrm{~L}$ regions. Phylogenetic analyses were performed by maximum parsimony, maximum likelihood, and Bayesian inference. Overall, the best-supported topology for the relationships among families within the order places the pair of Leguminosae and Polygalaceae as sister to the pair of Quillajaceae and Surianaceae. However, our approximately unbiased (AU) test of the combined data results has shown that none of the seven different topologies rejected. Furthermore, three topologies were not significantly different from each other. Therefore, similar to the previous studies, this study did not find wellsupported dichotomous relationships among the four Fabales families. The Fabales topology was very sensitive to both data choice and the phylogenetic methods used, which may indicate a rapidnear-simultaneous evolution of the four Fabales families. Our results also show that while nuclear sqd1 can be helpful as a complementary region, both the nuclear sqd1 and rDNA $26 \mathrm{~S}$ regions could be problematic when analysed individually.

Keywords - Fabales, Leguminosae, matK, Polygalaceae, Quillajaceae, rbcL, sqd1, Surianaceae, $26 \mathrm{~S}$.

\section{INTRODUCTION}

The last decades have seen an exponential increase in molecular phylogenetic studies of angiosperms and emerging consensus at higher levels. The order Fabales Bromhead was one of the most surprising angiosperm clades to result from early studies of interfamilial relationships. Since four families of Fabales are very diverse morphologically, (APG III 2009; Bello et al. 2009); until DNA sequence data became available, most of classification systems placed only the Leguminosae (Fabaceae) Juss. in the order Fabales, while the other families now placed in the order, Polygalaceae 
Hoffmanns. \& Link, Surianaceae Arn., and Quillajaceae D. Don, appeared in different taxonomic groups (Bello et al. 2009).

Molecular studies and fossil evidence suggest an ancient origin and rapid radiation for Fabales (e.g., Crane et al. 1990; Zi-Chen et al. 2004; Lavin et al. 2005; Pigg et al. 2008; Bello et al. 2009) (note that the unconfirmed fossils of Polygalaceae and Surianaceae, and there is still the possibility of incomplete fossil record of Fabales). The monophyly of the order is strongly supported by several studies (e.g., Bello et al. 2009; Bello et al. 2012; APG IV 2016), but the overall phylogenetic relationships across the order and position of the root remain controversial; a situation common in higher level phylogenetic studies of ancient, rapid radiations. (Bello et al. 2009). Previous studies which have recovered different interfamilial topologies for Fabales have used different DNA regions and have very different and unbalanced taxon sampling (e.g. Crayn et al. 1995; Doyle et al. 2000; Savolainen et al. 2000; Soltis et al. 2000; Kajita et al. 2001; Persson 2001; Wojciechowski et al. 2004; Lavin et al. 2005; Forest et al. 2007; Bruneau et al. 2008; Soltis et al. 2011). Phylogenetic instability has been attributed not only to the putative rapid radiation in the early history of the order, but also to sampling directed above (i.e. angiosperms) or below (i.e. Leguminosae, Polygalaceae) the ordinal level (Bello et al. 2009). Nevertheless, even studies focused on Fabales could not yield robust relationships for the order (Table 1).

The most comprehensive studies addressing the phylogeny of order Fabales were by Bello and colleagues (Bello et al. 2009; Bello et al. 2012). In their first study, five different topologies were recovered using maximum parsimony (MP) and Bayesian analysis (BI) based on the rbcL and matK plastid regions (Table 1). The Shimodaira-Hasegawa test (Shimodaira and Hasegawa 1999) they conducted favoured a resolved topology over a polytomy, but none of the five possible topologies outlining the relationships between the four families of Fabales received a significantly better likelihood. In all analyses, Fabales and each of its component families were monophyletic and 
support values were mostly very high for all these clades. However, all five topologies for interfamilial relationships within the order received low to moderate support, an observation common to many rosid orders and attributed to rapid, early radiation within Fabales (Bello et al. 2009; Wang et al. 2009). Furthermore, Bello et al. (2009) reported that the stem age estimate for Leguminosae, Polygalaceae and the pair Surianaceae+Quillajaceae have very similar ages, which would support the idea of a rapid radiation in the early history of the order.

In their second study (Bello et al. 2012), two hypotheses emerged from the combination of 66 morphological characters with previously published $r b c \mathrm{~L}$ and matK plastid regions. The morphological characters described floral development and anatomy, and $\mathrm{MP}$ and $\mathrm{BI}$ analyses were used to explore three data sets which differed in the proportion of missing data and in the choice of outgroup taxa (Table 1). The two recovered topologies were $(((S+Q) L) P)$ and $(L+P)(S+Q)$, with the latter only recovered from $\mathrm{Bl}$ analyses of the most densely-sampled matrices (Table 1). The most frequently-recovered topology, $(((S+Q) L) P)$ was considered the most likely in the light of morphology, in spite of low to moderate support from both MP and BI analyses.

Despite the attention phylogenetic relationships within Fabales has received, a well-supported interfamilial topology remains elusive. This unresolved phylogeny problem of Fabales also causes unanswered evolutionary questions such as estimating diversification rates (e.g., Smith et al. 2011; Koenen et al. 2013) and understanding trait evolution and biogeography. Therefore, an unambiguous phylogenetic answer for the four Fabales families is required. Moreover, the genomic markers used to date in phylogenetic reconstructions within the order have mostly been from the plastid genome. However, the prevailing view is that nuclear and plastid DNA sequence data are needed to fully understand flowering plant evolutionary history, because nuclear regions can provide insights into hybridization, polyploidy and reticulation (Sang 2002; Álvarez and Wendel 
2003). Therefore, in the present study, 26S rDNA sequence data is explored alongside previously published sqd1 data from the nuclear genome, and matK and $r b c \mathrm{~L}$ data from the plastid genome.

sqd1 (UDP sulfoquinovose synthase gene) is a low copy nuclear gene and it is one of the five conserved orthologue set (COS) markers highlighted in a survey of universally amplifiable markers; it is 267 base pairs (bp) long in Angiosperm families, easy to align due to the lack of indels and highly parsimony informative (Li et al. 2008). Babineau et al. (2013) screened the phylogenetic utility of 19 low copy nuclear genes for caesalpinoid legumes, and they highlighted that the sqd1 region has a potential for familial to tribal level resolution with almost $30 \%$ of parsimony informative characters.

The 265 nuclear ribosomal DNA (rDNA) has been used in several phylogenetic studies (e.g. Fan 2001; Soltis et al. 2001; Zanis et al. 2003; Weitemier et al. 2015; Xu et al. 2015). It has potentially many advantages for phylogenetic reconstruction: 1) it consists of both variable and conserved regions suitable for closely and distantly related taxa; 2 ) it has very high copy numbers making amplification generally easy with mostly universal primers (Baldwin et al. 1995; Bailey et al. 2003; Weitemier et al. 2015; Xu et al. 2015); and 3) like all nuclear loci, it is biparentally inherited providing insights into hybrid parentage, polyploidy events and reticulation (Álvarez and Wendel 2003). However, some drawbacks were also reported related to its high copy number, such as intra-individual and intragenomic variation with multiple copy types found within individuals, often incomplete and bidirectional homogenization of copy types, incomplete concerted evolution, paralogy problems, secondary structures, high GC content and the presence of potentially non-functional pseudogene sequences (Hillis and Dixon 1991; Baldwin 1992; Baldwin et al. 1995; Soltis and Soltis 1998; Alvarez and Wendel 2003; Bailey et al. 2003). Among them the view on inclusion/exclusion of pseudogenes changes from one study to another (Bailey et al. 2003). While some authors exclude potential pseudogenes due to alignment or long-branch attraction concerns (LBA; Felsenstein 1978), others 
include them to address issues related to the potential reticulate evolution of taxa. Many approaches such as pairwise comparisons and tree-based methods were applied to detect these pseudogenes (e.g., Hughes et al. 2002).

Despite the apparent early enthusiasm for the $26 \mathrm{~S}$ gene and its potential in phylogenetics, the $26 \mathrm{~S}$ rDNA region's popularity fell due to the increased interest for low-copy nuclear genes and the low phylogenetic signal subsequently reported for the region (Soltis et al. 2011). The extent of how above-mentioned issues affect phylogenetic reconstruction varies among groups of organisms. For example, phylogenetic studies rated the inclusion of the 265 conserved rDNA sequences from useful (e.g. Fan 2001; Neyland 2002; Soltis et al. 2011) to inconsistant (e.g. Ro et al. 1997; Muellner et al. 2003).

The matK plastid region is one of the most frequently employed genes in phylogenetic analyses (e.g. Hilu et al. 2003; Luckow et al. 2003; Wojciechowski et al. 2004; Lavin et al. 2005; Kim and Kim 2011; Wanntorp et al. 2011; Kim et al. 2013; LPWG 2017). It was shown, not only for Leguminosae but also for Fabales, that this plastid gene successfully resolves many relationships with high support due to its high substitution rate (Lavin et al. 2005; Bello et al. 2009; LPWG 2017). Similarly, the rbcL region is another commonly sequenced plastid gene for Fabales. While the use of this gene for Fabales was not recommended (Bello et al. 2009), nor was it as useful as matK for Leguminosae (Lavin et al. 2005), the possibility of it contributing to a robust combined analysis should not be ruled out.

In the present study, a broader outgroup sampling compared to previous studies of Fabales was employed to reduce tree imbalance artefacts (Smith 1994), and particularly to reduce problems associated with LBA (Felsenstein 1978) by breaking long branches between the ingroup and outgroup. The 34 outgroup taxa used here were chosen to represent each family from seven Fabidae orders. Additionally, as well as combining new nuclear sequence data and previously published 
nuclear and plastid regions, these regions were compared to investigate possible incongruence between them. Lastly, three analytical methods MP, maximum likelihood (ML) and BI were used to investigate how these approaches perform with the new data sets.

\section{MATERIALS AND METHODS}

\section{Taxon sampling}

Total genomic DNA samples used in Forest (2004) were newly sequenced here for 265 rDNA. The National Center for Biotechnology Information (NCBI/GenBank) accession numbers for previously published and newly produced DNA sequences are provided in Appendix 1, including $7026 \mathrm{~S}$ rDNA sequences. The taxon sampling list is organised according to the most recent classification system (e.g. Gagnon et al. 2016 and LPWG 2017). We included 34 taxa from seven different orders of Fabidae as outgroup taxa.

\section{DNA extraction, amplification and sequencing}

Approximately $950 \mathrm{bp}$ of the $5^{\prime}$-end of the $26 \mathrm{~S}$ rDNA gene was amplified using primers N-nc26S1 and 950rev (Kuzoff et al. 1998). Amplification was performed using the following program: 2 min at $94^{\circ} \mathrm{C}$, 32 cycles of $45 \mathrm{sec}$ at $94^{\circ} \mathrm{C}$, annealing at $55^{\circ} \mathrm{C}$ for $1 \mathrm{~min}, 1,5 \mathrm{~min}$ at $72^{\circ} \mathrm{C}$, and a final extension of 5 $\min$ at $72^{\circ} \mathrm{C}$. When PCR product yields were too low, one of the following additional steps was performed: (1) an increase in number of cycles (e.g. up to 35 cycles); (2) an additional PCR run using identical parameters as above repeated with 8 to 10 cycles; (3) three identical non-modified reactions pooled together on the same column for the cleaning step. All PCR products were purified with the QIAquick PCR purification kit (Qiagen inc.) and eluted in EB buffer (10 mM Tris). Complementary strands were sequenced on an $A B I 377$ or $A B I 3100$ automated sequencer following the manufacturer's protocols. The same primers were used for amplification and for the cycle sequencing reactions. Seventy previously unpublished $26 \mathrm{~S}$ rDNA sequences were included (Forest 2004), and 15 were downloaded from GenBank (Appendix 1). A total of 85 samples were included, 
43 from Leguminosae, 17 from Polygalaceae, four from Surianaceae and 21 outgroup taxa representing diverse Fabidae orders. Unfortunately, $26 \mathrm{~S}$ region could not be amplified for Quillaja.

Since sequencing results do not clearly indicate the presence of paralogous copies and/or pseudogenes (e.g. no significant double peaks in chromatograms), this has not been investigated further here for the 265 nuclear gene region.

\section{Phylogenetic analyses and model selection}

Sequences were assembled and aligned using the Geneious alignment option in Geneious Pro 4.8.4 (Kearse et al. 2012) with the automatic pairwise alignment tool and subsequently edited manually. Equivocal base calling at the beginning and end of assembled complementary strands were trimmed. All indels were scored as missing data. Eight different combined analyses were performed to explore the results obtained with the newly produced $26 \mathrm{~S}$ and published sqd1 nuclear partitions separately and in combination with published matK and $r b c \mathrm{~L}$ sequences (sqd 1 alone, $26 \mathrm{~S}$ alone, $26 \mathrm{~S}+s q d 1$ combined, matK+rbcL combined, sqd1+matK combined, 26S+sqd1+matK combined, sqd1+matK+rbcL combined, and $26 \mathrm{~S}+\mathrm{sqd} 1+m a t \mathrm{~K}+r b c \mathrm{~L}$ combined); details of each analysis are presented in Table 2. The substitution models for each of the individual genes were estimated using jModelTest2.1.10 (Guindon and Gascuel 2003; Darriba et al. 2012).

Maximum parsimony analysis was performed using PAUPRat (parsimony ratchet searches using PAUP*; (Sikes and Lewis 2001) as implemented on the CIPRES portal ((Miller et al. 2010); http://www.phylo.org/). Heuristic searches were performed with 1,000 replicates with treebisection-reconnection (TBR) branch swapping and a maximum of 1,000 best trees kept. All characters were equally weighted and unordered. Strict consensus trees were generated using PAUP and all the best trees found. 
Maximum likelihood analysis was performed using RAxML version 8 (Stamatakis 2014) as implemented on the CIPRES portal ((Miller et al. 2010); http://www.phylo.org/). The GTRGAMMA model was applied to each partition individually and default maximum likelihood search options were selected with 1000 bootstrap replicates. The best scoring trees with bootstrap values were saved.

Bayesian analyses were conducted using MrBayes 3.2.7a (Ronquist et al. 2012) as implemented on the CIPRES portal ((Miller et al. 2010); http://www.phylo.org/). The same GTR+G+I model of molecular evolution as for ML was applied. MrBayes was run with four (one cold and three heated) Monte Carlo Markov chains (MCMC) and for 100 million generations, sampling one tree in every 1,000 generations. This was repeated twice as independent runs, and the resulting parameter files were jointly visualized in Tracer (Rambaut and Drummond 2003) to ensure convergence. Among the 100,000 trees thus obtained, the first 25,000 trees (25\%) were discarded as "burn-in", and a maximum credibility tree and associated posterior probabilities were compiled using the remaining 75,000 trees and the "halfcompat" option of the "sumt" command. Images of the phylogenetic trees were produced using the Interactive Tree of Life (iTOL) online tool (https://itol.embl.de/) (Letunic and Bork 2016).

\section{Alternative topology testing}

The approximately unbiased (AU) (Shimodaira and Hasegawa 1999) test was used to evaluate the alternative phytogenetic relationships of the four Fabales families. For each alternative topology, $P$ values were calculated by W-IQ-TREE (http://iqtree.cibiv.univie.ac.at/, Trifinopoulos et al. 2016) by using 10,000 bootstrap replicates and our $26 \mathrm{~S}+s q d 1+m a t \mathrm{~K}+r b c \mathrm{~L}$ combined alignment.

\section{RESULTS}


The GTR+G+I model of molecular evolution was selected as the most suitable for each of the individual genes. In the following sections, the results of the $\mathrm{ML}$ and $\mathrm{BI}$ analyses are highlighted with MP topology summaries presented in Table 3 alongside those obtained from the ML and BI analyses. Only bootstrap support values above $50 \%$ or posterior probabilities above 0.95 are discussed. Alignment details for all datasets are also summarized in Table 2 (Online resource 1-8).

Fabales is found to be monophyletic in all analyses based on sqd1 (MP, ML and BI), but interfamilial relationships other than the Leguminosae-Polygalaceae pair were not resolved (Table 3, Online resource 9). Polygalaceae is monophyletic in all analyses, and Xanthophyllum sp. is retrieved as sister to the remainder of the family. Within the monophyletic Leguminosae, all six newly recognized subfamilies are also monophyletic, except in the MP analyses in which subfamily Papilionoideae is paraphyletic. For the analyses performed with the 26S rDNA region alone (Online resource 10), both Fabales and its constituent families were resolved as monophyletic in the ML analysis (only 57\%) and $\mathrm{BI}$ analysis (posterior probability of 1.0), but not in the MP analysis. However, the position of both Detarium (a member of subfamily Detarioideae) and Acrocarpus (a member of subfamily Caesalpinioideae) within Caesalpinioideae and Papilionoideae, respectively, was never seen in any previous analyses (e.g., LPWG 2017),

In the nuclear 26S+sqd1 ML analysis (Online resource 11), except Caesalpinioideae and Detarioideae, the remaining subfamilies were monophyletic. However, in the plastid matK+rbcL ML analysis, the phylogenetic relationships of the six subfamilies supports the new classification of the LPWG (2017), all the subfamilies were monophyletic (Online resource 12). In both analyses (matK+rbcL and $265+s q d 1$ ), Leguminosae was sister to Polygalaceae (with only $60 \%$ bootstrap support compared to $68 \%$ from the nuclear regions analysis). Quillajaceae was sister to Surianaceae with $85 \%$ bootstrap support in the plastid ML analysis, while in the nuclear tree the position of these two families were not resolved. Lastly, in contrast to highly supported monophyletic Fabales $(100 \%)$ in the plastid tree, 
in the nuclear tree the monophyly of the order Fabales was supported by only $71 \%$ bootstrap support.

The $26 \mathrm{~S}+s q d 1+m a t \mathrm{~K}+r b c \mathrm{LL}$ analysis yielded monophyletic Fabales (100\%), Fabales families, Leguminosae subfamilies and Polygalaceae tribes (Fig. 1). While a $(L+P)(Q+S)$ topology was observed with moderate bootstrap support (90\% bootstrap support for (L+P) and $88 \%$ bootstrap support for $(Q+S))$. Within Leguminosae all six subfamilies were monophyletic. Within monophyletic Polygalaceae (100\%), Xanthophylleae was sister to the remainder of the family.

The addition of 26S rDNA data to the other data sets did not yield higher support or better resolution (Table 3 and Table 4). In contrast to $83 \%$ bootstrap support for the $(L+P)$ clade in the sqd 1 $\mathrm{ML}$ tree, this clade was supported with $68 \%$ bootstrap support in the $s q d 1+26 \mathrm{~S} \mathrm{ML}$ analysis. Similarly, the addition of $26 \mathrm{~S}$ nuclear data to the $s q d 1+m a t \mathrm{~K}$ and $s q d 1+m a t \mathrm{~K}+r b c \mathrm{~L}$ did not yield better results. When matK is added, generally higher support values were obtained for all analyses, however when the rbcL is added, slightly lower values were observed (Table 3 and 4). Lastly, our approximately unbiased $(\mathrm{AU})$ test analysis showed that $((\mathrm{L}+\mathrm{P})(\mathrm{S}+\mathrm{Q}))$ topology $(1)$ was not significantly better than the other hypotheses (Table 5).

\section{DISCUSSION}

Our results have shown that, while the sqd1 nuclear region may not be helpful in solving Fabales phylogeny problems on its own due to reduced support for interfamilial relationships, it can be used in combination with other regions such as matk. On the other hand, there was no difference with regard to phylogenetic relationships between analyses including $26 \mathrm{~S}$ and those excluding it. While our sequencing results do not clearly indicate the presence of paralogous copies and/or pseudogenes (please note that this has not been investigated in depth here with additional 
analyses), it is possible that our $26 \mathrm{~S}$ dataset includes paralogous copies and/or pseudogenes which are causing Caesalpinioideae and Papilionoideae to be represented as non-monophyletic. Indeed, similar results were reported by a recent study (Maia et al. 2014) using both $26 \mathrm{~S}$ and $18 \mathrm{~S}$ nuclear regions in an angiosperm-wide study (e.g., non-monophyletic Fabales, Leguminosae and Polygalaceae). Furthermore, lack of support across the majority of nodes in the $26 \mathrm{~S}$ tree, especially for Leguminosae, is another concern (Online resource 11), which could be linked to the conserved nature of the region (Kuzoff et al. 1998). Therefore, the inclusion of $26 \mathrm{~S}$ in any phylogenetic study should assess possible paralogy problems, as well as how its contribution to support and topology is compared to analyses excluding it.

Our results have shown that both the topology and the root of the order change according to choice of genes and the analytical methods (Table 3), which was also common in the previous studies that focussed on Fabales. Moreover, two possible topologies were recovered from our analyses, $(L+P)(Q+S)$ obtained for most analyses, and $(((L+P) S) Q)$ for MP analyses of $26 S+s q d 1$ (Table 3$)$. Overall, our results indicate that the $((L+P)(S+Q))$ topology is the most likely; which is the same topology that was recovered from the BI analyses of matK and matK+rbcL by (Bello et al. 2009) and again from the BI analyses of matrix A and C of (Bello et al. 2012) (Table 1). However, similar to the previous studies (e.g., Forest 2004; Bello et al. 2009; Bello et al. 2012), it was found that both ML and $\mathrm{BI}$ analyses yielded low support values for the interfamilial relationships within Fabales. Furthermore, none of the seven different topologies were rejected by the AU test of our combined data, and the first three topologies were not significantly different from each other (Table 4). Indeed, this may indicate that the phylogenetic signal in the internal branches of Fabales is very weak that it is open to any small changes, which is a common feature of rapid radiations (RotaStabelli and Telford 2008; Roberts et al. 2009). However, Fabales is not one of the hard polytomy cases reported to date (Bello et al. 2009), in which the genes that are used may not have any 
phylogenetic signal for the internal branches (Braby et al. 2005; Whitfield and Kjer 2008; Kodandaramaiah et al. 2010).

Lack of resolution is a common problem across Angiosperms in general (e.g., Zeng et al. 2014; Huang et al. 2015; LPWG 2017) and there are several common reasons underlying not only unresolved rapid radiations but most phylogenetic problems, such as, gene tree incongruence due to biological events (e.g., whole genome duplication (WGD), hybridization, introgression, horizontal gene transfer, incomplete lineage sorting (ILS), extinction) (e.g., Koenen et al. 2019), outgroup problems (i.e., lack of an extant outgroup/closely related outgroup or the effect of the outgroup on ingroup topology) (e.g., Huerta-Cepas et al. 2014), or just systematic errors such as taxon sampling (Thomas et al. 2013), appropriate outgroup choice (i.e., possible systematic biases related to the outgroup sequences, such as low substitution rate and not ingroup-like $\mathrm{G}+\mathrm{C}$ composition) (e.g., Rota-Stabelli and Telford 2008), LBA (e.g., Qui et al. 2001), inadequate data and inaccurate model implementation (e.g., Reddy et al. 2017; Morgan et al. 2013).

A recent study has shown that the root of Leguminosae is particularly difficult, due to several WGD events, a combination of short internal and long external branches (i.e., extinction and rapid divergence, respectively), ILS and/or reticulation (Koenen et al. 2019) (please see also Cannon et al. 2015 and Wong et al. 2017). Furthermore, it was also argued that obtaining a fully bifurcated legume tree may not be possible due to the simultaneous/near-simultaneous origin of the family (Koenen et al. 2019). Indeed, conflict is very widespread, and it is quite possible that every gene tree is incongruent with the species tree, with these incongruences being stronger for the short-internal nodes (Salichos et al. 2014), and the same evolutionary history would also be possible for the order Fabales, and even thousands of genes may not be enough to solve the Fabales phylogeny, similar to the case of Leguminosae. On the other hand, we think that LBA may not be a problem for Fabales, because in the presence of LBA the root of the group is not stable when sampling different 
outgroups (Qui et al. 2001), which is not the case for Fabales (e.g., Bello et al. 2009; Bello et al. 2012; current study). Furthermore, to overcome a possible LBA problem, we employed a broad outgroup sampling strategy (Smith 1994; Lyons-Weiler et al. 1998; Djernæs et al. 2012; Drew et al. 2014) and performed Bayesian analyses that are less vulnerable to LBA artefacts, compared to parsimony analyses (Bergsten 2005), yet both the root and topology of the tree changed according to the phylogenetic method, and genes used. However, the effect of data sampling, model implementation, outgroup choice and taxon sampling need further analyses, and future studies should focus on these possible causes for the unresolved Fabales phylogeny.

In conclusion, as with previous studies, this study did not find well-supported dichotomous relationships among the four Fabales families, which may indicate a rapid-near-simultaneous evolution of the four Fabales families. Therefore, it should not be concluded that $((L+P)(Q+S))$ is the "definitive answer" for relationships within Fabales, as there is still a need for further studies to not only confirm whether $((L+P)(Q+S))$ or another topology is the right answer for the order, but also to reveal the underlying reason for the unresolved phylogeny within Fabales. However, we think that this and previous studies dealing with interfamilial Fabales relationships will provide the framework for future genomic studies that address the issue. Further work is certainly needed to solve the Fabales puzzle with confidence, and to approach the underlying problem from a direction other than employing conventional phylogeny methods.

\section{ACKNOWLEDGMENTS}

We would like to thank Professor Anne Bruneau (Universite de Montreal, Canada) and Dr. Colin Hughes (Universitat Zurich, Switzerland) for their valuable suggestions, and anonymous reviewers for helpful comments. The first author also thanks Professor Darren Crayn (James Cook University, Australia) for sending some samples. 


\section{Compliance with ethical standards}

The authors declare compliance with ethical standards.

\section{Conflict of interest}

The authors declare that they have no conflict of interest.

\section{Information on Electronic Supplementary Material}

Online resource 1. sqd1 sequence alignment in nexus format

Online resource $2.26 \mathrm{~S}$ sequence alignment in nexus format

Online resource 3. sqd1+26S sequence alignment in nexus format

Online resource 4. matK+rbcL sequence alignment in nexus format

Online resource 5. sqd1+matK sequence alignment in nexus format

Online resource 6. sqd1+matK+rbcL sequence alignment in nexus format

Online resource 7. sqd1+26S+matK sequence alignment in nexus format

Online resource 8. sqd1+26S+matK+rbcL sequence alignment in nexus format

Online resource 9. Maximum likelihood tree of the nuclear sqd1 data set. Outgroup taxa, Polygalaceae, Surianaceae, Quillajaceae and Leguminosae are indicated. Bootstrap values are indicated below branches.

Online resource 10. Maximum likelihood tree of the nuclear 26S data set. Outgroup taxa, Polygalaceae, Surianaceae, Quillajaceae and Leguminosae are indicated. Bootstrap values are indicated below branches. 
Online resource 11. Maximum likelihood tree of the combined nuclear sqd1+26S data sets. Outgroup taxa, Polygalaceae, Surianaceae, Quillajaceae and Leguminosae are indicated. Bootstrap values are indicated below branches.

Online resource 12. Maximum likelihood tree of the combined plastid matK+rbcL data sets.

Outgroup taxa, Polygalaceae, Surianaceae, Quillajaceae and Leguminosae are indicated. Bootstrap values are indicated below branches.

\section{LITERATURE CITED}

Álvarez I, Wendel JF (2003) Ribosomal ITS sequences and plant phylogenetic inference. Mol Phylogenet Evol 29: 417-434. https://doi.org/10.1016/S1055-7903(03)00208-2

Angiosperm Phylogeny Group (2009) An update of the Angiosperm Phylogeny Group classification for the orders and families of flowering plants: APG III. J Linn Soc Bot 161: 105-121. https://doi.org/10.1111/j.1095-8339.2009.00996.x

Angiosperm Phylogeny Group (2016) An update of the Angiosperm Phylogeny Group classification for the orders and families of flowering plants: APG IV J. Linn Soc Bot 181: 1-20. https://doi.org/10.1111/boj.12385

Babineau M, Gagnon E, Bruneau A (2013) Phylogenetic utility of 19 low copy nuclear genes in closely related genera and species of caesalpinioid legumes. S Afr J Bot 89: 94-105. https://doi.org/10.1016/j.sajb.2013.06.018

Bailey CC, Carr TG, Harris SA, Hughes CE (2003) Characterization of angiosperm nrDNA polymorphism, paralogy, and pseudogenes. Mol Phylogenet Evol 29: 435-455. https://doi.org/10.1016/j.ympev.2003.08.021

Baldwin BG (1992) Phylogenetic utility of the internal transcribed spacers of nuclear ribosomal DNA in plants: an example from the Compositae. Mol Phylogenet Evol 1: 3-16. https://doi.org/10.1016/1055-7903(92)90030-K

Baldwin BG, Sanderson MJ, Porter JM, Wojciechowski MF, Campbell CS, Donoghue MJ (1995) The ITS region of nuclear ribosomal DNA: a valuable source of evidence on angiosperm phylogeny. Ann Mo Bot Gard 247-277. https://doi.org/10.2307/2399880

Bello MA, Bruneau A, Forest F, Hawkins JA (2009) Elusive relationships within order Fabales: phylogenetic analyses using matK and $r b c L$ sequence data. Syst Bot 34: 102-114. https://doi.org/10.1600/036364409787602348

Bello MA, Rudall PJ, Hawkins JA (2012) Combined phylogenetic analyses reveal interfamilial relationships and patterns of floral evolution in the eudicot order Fabales. Cladistics 28: 393421. https://doi.org/10.1111/j.1096-0031.2012.00392.x

Bergsten J (2005) A review of long-branch attraction. Cladistics 21: 163-193. https://doi.org/10.1111/j.1096-0031.2005.00059.x

Braby MF, Trueman JW, Eastwood R (2005). When and where did troidine butterflies (Lepidoptera: Papilionidae) evolve? Phylogenetic and biogeographic evidence suggests an origin in remnant Gondwana in the Late Cretaceous. Invertebr Syst 19: 113-143. https://doi.org/10.1071/IS04020

Bruneau A, Mercure M, Lewis GP, Herendeen PS (2008) Phylogenetic patterns and diversification in the caesalpinioid legumes. This paper is one of a selection of papers published in the Special Issue on Systematics Research. Botany 86: 697-718. https://doi.org/10.1139/B08-058 
Cannon SB, Mckain MR, Harkess A, Nelson MN, Dash S, Deyholos MK, Peng Y, Joyce B, Stewart Jr CN, Rolf M, Kutchan T (2015) Multiple polyploidy events in the early radiation of nodulating and nonnodulating legumes. Mol Biol Evol 32: 193-210. https://doi.org/10.1093/molbev/msu296

Crane P, Manchester S, Dilcher D (1990) Fossil leaves and well-preserved reproductive structures from the Fort Union Formation (Paleocene) near Almont. North Dakota, USA. Fieldiana Geol 20: 1-63.

Crayn DM, Fernando ES, Gadek PA, Quinn CJ (1995) A reassessment of the familial affinity of the Mexican genus Recchia Mocino \& Sessé ex DC. Brittonia 47: 397-402. https://doi.org/10.2307/2807568

Darriba D, Taboada GL, Doallo R, Posada D (2012) jModelTest 2: more models, new heuristics and parallel computing. Nat Methods 9: 772-772. https://doi.org/10.1038/nmeth.2109

Djernaes M, Klass KD, Picker MD, Damgaard J (2012) Phylogeny of cockroaches (Insecta, Dictyoptera, Blattodea), with placement of aberrant taxa and exploration of out-group sampling. Syst Entomol 37: 65-83. https://doi.org/10.1111/j.1365-3113.2011.00598.x

Doyle JJ, Chappill JA, Bailey CD, Kajita T (2000) Towards a comprehensive phylogeny of legumes: evidence from $r b c L$ sequences and non-molecular data. Advances in Legume Systematics, Part 9, 1-20. Royal Botanic Gardens, Kew: London.

Drew BT, Ruhfel BR, Smith SA, Moore MJ, Briggs BG, Gitzendanner MA, Soltis PS, Soltis DE (2014) Another look at the root of the angiosperms reveals a familiar tale. Syst. Biol. 63: 368-82. https://doi.org/10.1093/sysbio/syt108

Fan CX, Qiu-Yun (2001) Phylogenetic relationships within Cornus (Cornaceae) based on 26S rDNA sequences. Am J Bot 88: 1131-1138. https://doi.org/10.2307/2657096

Felsenstein J (1978) Cases in which parsimony or compatibility methods will be positively misleading. Syst Biol 27: 401-410. https://doi.org/10.1093/sysbio/27.4.401

Forest $\mathrm{F}$ (2004) Systematics of Fabales and Polygalaceae, with emphasis on Muraltia and the origin of the Cape flora. Reading: University of Reading.

Forest F, Chase MW, Persson C, Crane PR, Hawkins JA (2007) The role of biotic and abiotic factors in evolution of ant dispersal in the milkwort family (Polygalaceae). Evolution 61: 1675-94. https://doi.org/10.1111/j.1558-5646.2007.00138.x

Gagnon E, Bruneau A, Hughes CE, de Queiroz LP, Lewis GP (2016) A new generic system for the pantropical Caesalpinia group (Leguminosae). PhytoKeys 71: 1-160. https://doi.org/10.3897/phytokeys.71.9203

Guindon S, Gascuel O (2003). A simple, fast and accurate method to estimate large phylogenies by maximum-likelihood. Syst Biol 52: 696-704. https://doi.org/10.1080/10635150390235520

Hillis DM, Dixon MT (1991) Ribosomal DNA: molecular evolution and phylogenetic inference. Q Rev Biol 411-453. https://doi.org/10.1086/417338

Hilu KW, Borsch T, Müller K, Soltis DE, Soltis PS, Savolainen V, Chase MW, Powell MP, Alice LA, Evans $\mathrm{R}$ (2003) Angiosperm phylogeny based on matK sequence information. Am J Bot 90: 17581776. https://doi.org/10.3732/ajb.90.12.1758

Huang C-H, Sun R, Hu Y, Zeng L, Zhang N, Cai L, Zhang Q, Koch MA, Al-Shehbaz I, Edger P P, Pires JC, Tan D-Y, Zhong Y, MA H (2015) Resolution of Brassicaceae phylogeny using nuclear genes uncovers nested radiations and supports convergent morphological evolution. Mol Biol Evol 33: 394-412. https://doi.org/10.1093/molbev/msv226

Huerta-Cepas J, Marcet-Houben M, Gabaldón T (2014) A nested phylogenetic reconstruction approach provides scalable resolution in the eukaryotic Tree of Life. PeerJ PrePrints 2:e223v1 https://doi.org/10.7287/peerj.preprints.223v1. https://doi.org/10.7287/peerj.preprints.223v1

Hughes CE, Bailey CD, Harris SA (2002) Divergent and reticulate species relationships in Leucaena (Fabaceae) inferred from multiple data sources: insights into polyploid origins and nrDNA polymorphism. Am J Bot 89: 1057-1073. https://doi.org/10.3732/ajb.89.7.1057 
Kajita T, Ohashi H, Tateishi Y, Bailey CD, Doyle JJ (2001) rbcL and legume phylogeny, with particular reference to Phaseoleae, Millettieae, and allies. Syst Bot 26: 515-536.

Kearse M, Moir R, Wilson A, Stones-Havas S, Cheung M, Sturrock S, Buxton S, Cooper A, Markowitz S, Duran C, Thierer T, Ashton B, Mentjies P, Drummond A (2012) Geneious Basic: an integrated and extendable desktop software platform for the organization and analysis of sequence data. Bioinformatics 28: 1647-1649. https://doi.org/10.1093/bioinformatics/bts199

Kim DK, Kim JH (2011) Molecular phylogeny of tribe Forsythieae (Oleaceae) based on nuclear ribosomal DNA internal transcribed spacers and plastid DNA trnL-F and matK gene sequences. J Plant Res 124: 339-47. https://doi.org/10.1007/s10265-010-0383-9

Kim JS, Hong JK, Chase MW, Fay MF, Kim JH (2013) Familial relationships of the monocot order Liliales based on a molecular phylogenetic analysis using four plastid loci: $m a t K, r b c L, a t p B$ and atpF-H. J Linn Soc Bot 172: 5-21. https://doi.org/10.1111/boj.12039

Kodandaramaiah U, Pena C, Braby MF, Grund R, Muller CJ, Nylin S, Wahlberg N (2010) Phylogenetics of Coenonymphina (Nymphalidae: Satyrinae) and the problem of rooting rapid radiations. Mol Phylogenet Evol 54: 386-94. https://doi.org/10.1016/j.ympev.2009.08.012

Koenen EJM, De Vos JM, Atchison GW, Simon MF, Schrire BD, De Souza ER, De Queiroz LP, Hughes CE (2013) Exploring the tempo of species diversification in legumes. S Afr J Bot 89: 19-30. https://doi.org/10.1016/j.sajb.2013.07.005

Koenen EJ, Ojeda DI, Steeves R, Migliore J, Bakker FT, Wieringa JJ, Kidner C, Hardy OJ, Pennington RT, Bruneau A, Hughes CE (2019) Large-scale genomic sequence data resolve the deepest divergences in the legume phylogeny and support a near-simultaneous evolutionary origin of all six subfamilies. New Phytol 225: 1355-1369. https://doi.org/10.1111/nph.16290

Kuzoff RK, Sweere JA, Soltis DE, Soltis PS, Zimmer EA (1998) The phylogenetic potential of entire 26S rDNA sequences in plants. Mol Biol Evol 15: 251-263.

https://doi.org/10.1093/oxfordjournals.molbev.a025922

Lavin M, Herendeen PS, Wojciechowski MF (2005) Evolutionary rates analysis of Leguminosae implicates a rapid diversification of lineages during the tertiary. Syst Biol 54: 575-94. https://doi.org/10.1080/10635150590947131

Letunic I, Bork P (2016) Interactive tree of life (iTOL) v3: an online tool for the display and annotation of phylogenetic and other trees. Nucleic Acids Res 44: W242-W245. https://doi.org/10.1093/nar/gkw290

Li M, Wunder J, Bissoli G, Scarponi E, Gazzani S, Barbaro E, Saedler H, Varotto C (2008) Development of $\mathrm{COS}$ genes as universally amplifiable markers for phylogenetic reconstructions of closely related plant species. Cladistics 24: 727-745. https://doi.org/10.1111/j.10960031.2008.00207.x

LPWG (2017) A new subfamily classification of the Leguminosae based on a taxonomically comprehensive phylogeny. Taxon 66: 44-77. https://doi.org/10.12705/661.3

Luckow M, Miller JT, Murphy DJ, Livshultz T (2003) A phylogenetic analysis of the Mimosoideae (Leguminosae) based on chloroplast DNA sequence data. Advances in Legume Systematics, Part 10, 197-220. Royal Botanic Gardens, Kew: London.

Lyons-Weiler J, Hoelzer GA, Tausch RJ (1998) Optimal outgroup analysis. Biol J Linn Soc 64: 493-511. https://doi.org/10.1111/j.1095-8312.1998.tb00346.x

Maia VH, Gitzendanner MA, Soltis PS, Wong GK-S, Soltis DE (2014) Angiosperm phylogeny based on 18S/26S rDNA sequence data: constructing a large data set using Next-Generation sequence data. Int J Plant Sci 175: 613-650. https://doi.org/10.1086/676675

Miller MA, Pfeiffer W, Schwartz T (2010) "Creating the CIPRES Science Gateway for inference of large phylogenetic trees" in Proceedings of the Gateway Computing Environments Workshop (GCE), 14 Nov. 2010, New Orleans, LA, 1-8. https://doi.org/10.1109/GCE.2010.5676129

Morgan CC, Foster PG, Webb AE, Pisani D, Mclnerney JO, O'Connell MJ (2013) Heterogeneous models place the root of the placental mammal phylogeny. Mol Biol Evol 30: 2145-2156. https://doi.org/10.1093/molbev/mst117 
Muellner AN, Samuel R, Johnson SA, Cheek M, Pennington TD, Chase MW (2003) Molecular phylogenetics of Meliaceae (Sapindales) based on nuclear and plastid DNA sequences. Am J Bot 90: 471-480. https://doi.org/10.3732/ajb.90.3.471

Neyland R (2002) A phylogeny inferred from large-subunit (26S) ribosomal DNA sequences suggests that Burmanniales are polyphyletic. Aust Syst Bot 15: 19-28. https://doi.org/10.1071/SB01001

Persson C (2001) Phylogenetic relationships in Polygalaceae based on plastid DNA sequences from the $t r n L-F$ region. Taxon 763-779. https://doi.org/10.2307/1223706

Pigg KB, Devore, ML, Wojciechowski MF (2008) Paleosecuridaca curtisii gen. et sp. nov., SecuridacaLike Samaras (Polygalaceae) from the Late Paleocene of North Dakota and their significance to the divergence of families within the Fabales. Int J Plant Sci 169: 1304-1313. https://doi.org/10.1086/591981

Qiu YL, Lee J, Whitlock BA, Bernasconi-Quadroni F, Dombrovska O (2001) Was the ANITA rooting of the angiosperm phylogeny affected by long-branch attraction? Mol Biol Evol 18: 1745-1753. https://doi.org/10.1093/oxfordjournals.molbev.a003962

Rambaut A, Drummond A (2003) Tracer: a program for analysing results from Bayesian MCMC programs such as BEAST \& MrBayes. University of Edinburgh, UK. Available at: http://beast.bio.ed.ac.uk/Tracer.

Reddy S, Kimball RT, Pandey A, Hosner PA, Braun MJ, Hackett SJ, Han KL, Harshman J, Huddleston CJ, Kingston S, Marks BD (2017) Why do phylogenomic data sets yield conflicting trees? Data type influences the avian tree of life more than taxon sampling. Syst Biol 66: 857-879. https://doi.org/10.1093/sysbio/syx041

Ro K-E, Keener CS, McPheron BA (1997) Molecular phylogenetic study of the Ranunculaceae: utility of the nuclear 26S ribosomal DNA in inferring intrafamilial relationships. Mol Phylogenet Evol 8: 117-127. https://doi.org/10.1006/mpev.1997.0413

Roberts TE, Sargis EJ, Olson LE (2009) Networks, trees, and treeshrews: assessing support and identifying conflict with multiple loci and a problematic root. Syst Biol 58: 257-270. https://doi.org/10.1093/sysbio/syp025

Ronquist F, Teslenko M, van der Mark P, Ayres DL, Darling A, Höhna S, Larget B, Liu L, Suchard MA, Huelsenbeck JP (2012) MRBAYES 3.2: Efficient Bayesian phylogenetic inference and model selection across a large model space. Syst Biol 61:539-542. https://doi.org/10.1093/sysbio/sys029

Rota-Stabelli O, Telford MJ (2008) A multi criterion approach for the selection of optimal outgroups in phylogeny: recovering some support for Mandibulata over Myriochelata using mitogenomics. Mol Phylogenet Evol 48: 103-11. https://doi.org/10.1016/j.ympev.2008.03.033

Salichos L, Stamatakis A, Rokas A., 2014. Novel information theory-based measures for quantifying incongruence among phylogenetic trees. Mol Biol Evol 31(5), 1261-1271. https://doi.org/10.1093/molbev/msu061

Sang T (2002) Utility of low-copy nuclear gene sequences in plant phylogenetics. Crit Rev Biochem Mol Biol 37: 121-147. https://doi.org/10.1080/10409230290771474

Savolainen V, Chase MW, Hoot SB, Morton CM, Soltis DE, Bayer C, Fay MF, De Bruijn AY, Sullivan S, Qiu Y-L (2000) Phylogenetics of flowering plants based on combined analysis of plastid atpB and $r b c L$ gene sequences. Syst Biol 49: 306-362. https://doi.org/10.1093/sysbio/49.2.306

Shimodaira H, Hasegawa M (1999) Multiple comparisons of log-likelihoods with applications to phylogenetic inference. Mol Biol Evol 16: 1114-1116. https://doi.org/10.1093/oxfordjournals.molbev.a026201

Sikes D, Lewis P (2001) Beta software, version 1. PAUPRat: PAUP* implementation of the parsimony ratchet. Distributed by the authors. Department of Ecology and Evolutionary Biology, University of Connecticut, Storrs, USA 
Smith AB (1994) Rooting molecular trees: problems and strategies. Biol. J. Linn. Soc. 51: 279-292. https://doi.org/10.1111/j.1095-8312.1994.tb00962.x

Smith SA, Beaulieu, JM, Stamatakis, A, Donoghue, MJ. 2011. Understanding angiosperm diversification using small and large phylogenetic trees. Am J Bot 98: 404-14. https://doi.org/10.3732/ajb.1000481

Soltis PS, Soltis DE (1998) Molecular evolution of 185 rDNA in angiosperms: implications for character weighting in phylogenetic analysis. In Molecular Systematics of Plants II, 188-210. Springer: US. https://doi.org/10.1007/978-1-4615-5419-6_7

Soltis DE, Soltis PS, Chase MW, Mort ME, Albach DC, Zanis M, Savolainen V, Hahn WH, Hoot SB, Fay MF, Axtell M, Swensen SM, Prince LM, Kress WJ, Nixon KC, Farris JS (2000) Angiosperm phylogeny inferred from $18 \mathrm{~S} r D N A, r b c L$, and $a t p B$ sequences. J Linn Soc Bot 133: 381-461. https://doi.org/10.1111/j.1095-8339.2000.tb01588.x

Soltis DE, Kuzoff RK, Mort ME, Zanis M, Fishbein M, Hufford L, Koontz J, Arroyo MK (2001) Elucidating deep-level phylogenetic relationships in Saxifragaceae using sequences for six chloroplastic and nuclear DNA regions. Ann Mo Bot Gard 669-693. https://doi.org/10.2307/3298639

Soltis DE, Smith SA, Cellinese N, Wurdack KJ, Tank DC, Brockington SF, Refulio-Rodriguez NF, Walker JB, Moore MJ, Carlsward BS (2011) Angiosperm phylogeny: 17 genes, 640 taxa. Am J Bot 98: 704-730. https://doi.org/10.3732/ajb.1000404

Stamatakis A (2014) RAxML version 8: a tool for phylogenetic analysis and post-analysis of large phylogenies. Bioinformatics 30: 1312-1313. https://doi.org/10.1093/bioinformatics/btu033

Thomas JA, Trueman JW, Rambaut A, Welch JJ (2013) Relaxed phylogenetics and the Palaeoptera problem: resolving deep ancestral splits in the insect phylogeny. Syst Biol 62: 285-297. https://doi.org/10.1093/sysbio/sys093

Trifinopoulos J, Nguyen LT, von Haeseler A, Minh BQ (2016) W-IQ-TREE: a fast online phylogenetic tool for maximum likelihood analysis. Nucleic Acids Res 44: W232-W235. https://doi.org/10.1093/nar/gkw256

Wang H, Moore MJ, Soltis PS, Bell CD, Brockington SF, Alexandre R, Davis CC, Latvis M, Manchester SR, Soltis DE (2009) Rosid radiation and the rapid rise of angiosperm-dominated forests. Proc Natl Acad Sci USA 106: 3853-8. https://doi.org/10.1073/pnas.0813376106

Wanntorp L, Gotthardt K, Muellner AN (2011) Revisiting the wax plants (Hoya, Marsdenieae, Apocynaceae): Phylogenetic tree using the matK gene and $p s b A-t r n H$ intergenic spacer. Taxon 60: 4-14. https://doi.org/10.1002/tax.601002

Weitemier K, Straub SC, Fishbein M, Liston A (2015) Intragenomic polymorphisms among high-copy loci: a genus-wide study of nuclear ribosomal DNA in Asclepias (Apocynaceae). PeerJ 3, e718. https://doi.org/10.7717/peerj.718

Whitfield JB, Kjer KM (2008) Ancient rapid radiations of insects: challenges for phylogenetic analysis. Annu Rev Entomol 53: 449-472. https://doi.org 10.1146/annurev.ento.53.103106.093304

Wojciechowski MF, Lavin M, Sanderson MJ (2004) A phylogeny of legumes (Leguminosae) based on analysis of the plastid matK gene resolves many well-supported subclades within the family. Am J Bot 91: 1846-1862. https://doi.org/10.3732/ajb.91.11.1846

Wong MM, Vaillancourt RE, Freeman JS, Hudson CJ, Bakker FT, Cannon CH, Ratnam W (2017) Novel insights into karyotype evolution and whole genome duplications in legumes. BioRxiv 099044. https://doi.org/10.1101/099044

Xu J, Xu Y, Yonezawa T, Li L, Hasegawa M, Lu F, Chen J, Zhang W (2015) Polymorphism and evolution of ribosomal DNA in tea (Camellia sinensis, Theaceae). Mol. Phylogenet. Evol. 89: 63-72. https://doi.org/10.1016/j.ympev.2015.03.020

Zanis MJ, Soltis PS, Qiu YL, Zimmer E, Soltis DE (2003) Phylogenetic analyses and perianth evolution in basal angiosperms. Ann Mo Bot Gard 129-150. https://doi.org/10.2307/3298579 
Zeng L, Zhang Q, Sun R, Kong H, Zhang N, Ma H (2014) Resolution of deep angiosperm phylogeny using conserved nuclear genes and estimates of early divergence times. Nature Commun 5 : 4956. https://doi.org/10.1038/ncomms5956

Zhi-Chen S, Wei-Ming W, Fei H (2004) Fossil pollen records of extant angiosperms in China. Bot Rev 70: 425-458. https://doi.org/10.1663/0006-8101(2004)070[0425:FPROEA]2.0.CO;2 
Table 1: Summary of previous studies focused on Fabales. In Forest's 2004 study "complete" refers to "all taxa regardless of the missing sequences" and "partial" refers to "only taxa for which all of the DNA regions were sequenced". In Bello et al. 's (2009) study the "reduced taxa" dataset consists of only taxa with both $r b c \mathrm{~L}$ and matK sequences available, while "all taxa" contains every available rbcL and matK sequences. In Bello et al. 's (2012) study, Matrix A, B and C are defined as follow: Matrix A includes all 75 taxa included in the morphological survey, whether or not molecular data were available; Matrix B includes 40 ingroup taxa for which morphology, $r b c \mathrm{~L}$ and or matK data were available; Matrix $\mathrm{C}$ comprises the broadest possible sampling with any marker available, $r b c \mathrm{~L}$, matK or morphology. $\mathrm{MP}=$ maximum parsimony, $\mathrm{ML}=$ maximum likelihood, $\mathrm{BI}=$ Bayesian inference, $\mathrm{L}=$ Leguminosae, $\mathrm{P}=\mathrm{Polygalaceae}, \mathrm{S}=$ Surianaceae, $Q=$ Quillajaceae.

\begin{tabular}{|c|c|c|c|c|}
\hline Study & Analyses & Topology & Ingroup & Outgroup \\
\hline \multirow[t]{4}{*}{ Forest, 2004} & $r b c \mathrm{~L}, \operatorname{trn\mathrm {L}-\mathrm {F}-\mathrm {MP}}$ & $((\mathrm{LP}) \mathrm{S}) \mathrm{Q}$ & $159(98 \mathrm{P}, 54 \mathrm{~L}, 6 \mathrm{~S}, 1 \mathrm{Q})$ & 8 taxa from diverse Fabidae \\
\hline & $r b c \mathrm{~L}$, trnL-F,26S-MP-complete & ((SP)L)Q & $159(98 \mathrm{P}, 54 \mathrm{~L}, 6 \mathrm{~S}, 1 \mathrm{Q})$ & 8 taxa from diverse Fabidae \\
\hline & $r b c \mathrm{~L}$, trnL-F,26S-MP-partial & ((LP)S)Q & $65(18 \mathrm{P}, 41 \mathrm{~L}, 5 \mathrm{~S}, 1 \mathrm{Q})$ & 8 taxa from diverse Fabidae \\
\hline & 26S-MP & Unresolved & $65(17 P, 43 L, 4 S, 1 Q)$ & 10 taxa from diverse Fabidae \\
\hline \multirow[t]{9}{*}{ Bello et al. 2009} & $r b c \mathrm{~L}-\mathrm{MP}$ & Unresolved & $152(93 P, 52 L, 6 S, 1 Q)$ & 14 taxa from diverse Fabidae \\
\hline & $r b c \mathrm{~L}-\mathrm{BI}$ & $((\mathrm{PS}) \mathrm{Q}) \mathrm{L}$ & $152(93 \mathrm{P}, 52 \mathrm{~L}, 6 \mathrm{~S}, 1 \mathrm{Q})$ & 14 taxa from diverse Fabidae \\
\hline & matK-MP & ((SQ)L)P & $70(36 \mathrm{~L}, 28 \mathrm{P}, 5 \mathrm{~S}, 1 \mathrm{Q})$ & 8 taxa from diverse Fabidae \\
\hline & matK-BI & $(\mathrm{LP})(\mathrm{SQ})$ & $70(36 \mathrm{~L}, 28 \mathrm{P}, 5 \mathrm{~S}, 1 \mathrm{Q})$ & 8 taxa from diverse Fabidae \\
\hline & rbcL-matK-MP-reduced taxa & $((\mathrm{LP}) \mathrm{S}) \mathrm{Q}$ & $70(36 \mathrm{~L}, 28 \mathrm{P}, 5 \mathrm{~S}, 1 \mathrm{Q})$ & 5 taxa from diverse Fabidae \\
\hline & rbcL-matK-BI-reduced taxa & ((LP)S)Q & $70(36 \mathrm{~L}, 28 \mathrm{P}, 5 \mathrm{~S}, 1 \mathrm{Q})$ & 5 taxa from diverse Fabidae \\
\hline & rbcL-matK-MP-all taxa & ((SQ)L)P & $152(93 \mathrm{P}, 52 \mathrm{~L}, 6 \mathrm{~S}, 1 \mathrm{Q})$ & 17 taxa from diverse Fabidae \\
\hline & rbcL-matK-BI-all taxa & (LP)(SQ) & $152(93 \mathrm{P}, 52 \mathrm{~L}, 6 \mathrm{~S}, 1 \mathrm{Q})$ & 17 taxa from diverse Fabidae \\
\hline & matK-molecular clock & ((SQ)L)P & $70(28 \mathrm{P}, 36 \mathrm{~L}, 5 \mathrm{~S}, 1 \mathrm{Q})$ & 7 taxa from diverse Fabidae \\
\hline \multirow[t]{7}{*}{ Bello et al. 2012} & Matrix A-MP & ((SQ)L)P & $74(48 P, 24 L, 1 S, 1 Q)$ & Krameria ixine \\
\hline & Matrix B-MP & $((\mathrm{SQ}) \mathrm{L}) \mathrm{P}$ & $40(20 P, 18 L, 1 S, 1 Q)$ & Krameria ixine \\
\hline & Matrix C-MP & ((SQ)L)P & $179(112 \mathrm{P}, 61 \mathrm{~L}, 5 \mathrm{~S}, 1 \mathrm{Q})$ & 17 taxa from diverse Fabidae \\
\hline & Matrix A-BI & (LP)(SQ) & $74(48 \mathrm{P}, 24 \mathrm{~L}, 1 \mathrm{~S}, 1 \mathrm{Q})$ & Krameria ixine \\
\hline & Matrix B-BI & $((\mathrm{SQ}) \mathrm{L}) \mathrm{P}$ & $40(20 P, 18 L, 1 S, 1 Q)$ & Krameria ixine \\
\hline & Matrix C-BI & (LP)(SQ) & $179(112 \mathrm{P}, 61 \mathrm{~L}, 5 \mathrm{~S}, 1 \mathrm{Q})$ & 17 taxa from diverse Fabidae \\
\hline & Only morphology & Unresolved & 75 taxa $(48 \mathrm{P}, 24 \mathrm{~L}, 1 \mathrm{~S}, 1 \mathrm{Q})$ & Gillenia trifoliata and Krameria ixine \\
\hline
\end{tabular}


Table 2: Eight phylogenetic analyses of order Fabales performed with different data sets. Analyses were designed to explore the data partitions alone and in different combinations. Alignment statistics for all datasets are indicated. L: Leguminosae, P: Polygalaceae, S: Surianaceae, Q: Quillajaceae.

\begin{tabular}{|l|l|l|l|l|l|l|l|l|}
\hline Data sets & $\begin{array}{l}\text { Total \# of } \\
\text { sequences }\end{array}$ & $\mathrm{L}$ & $\mathrm{P}$ & $\mathrm{S}$ & $\mathrm{Q}$ & $\begin{array}{l}\text { Outgroup } \\
\text { taxa }\end{array}$ & $\begin{array}{l}\text { Alignment } \\
\text { length }\end{array}$ & $\begin{array}{l}\text { \# of parsimony } \\
\text { informative } \\
\text { characters }\end{array}$ \\
\hline$s d q 1$ & 106 & 69 & 6 & 2 & 1 & 28 & 333 & $124(37 \%)$ \\
\hline $26 \mathrm{~S}$ & 85 & 43 & 17 & 4 & 0 & 21 & 935 & $200(21 \%)$ \\
\hline sqd1+matK & 106 & 69 & 6 & 2 & 1 & 28 & 2041 & $944(46 \%)$ \\
\hline $26 \mathrm{~S}+s q d 1$ & 121 & 71 & 17 & 4 & 1 & 28 & 1269 & $317(25 \%)$ \\
\hline matK+rbcL & 128 & 72 & 16 & 5 & 1 & 34 & 3140 & $1267(40 \%)$ \\
\hline $26 \mathrm{~S}+\mathrm{sqd} 1+$ matK & 131 & 73 & 18 & 5 & 1 & 34 & 3012 & $1217(40 \%)$ \\
\hline sqd1+matK+rbcL & 131 & 73 & 18 & 5 & 1 & 34 & 3474 & $1391(40 \%)$ \\
\hline $26 \mathrm{~S}+\mathrm{sqd} 1+\mathrm{matK}+r b c \mathrm{~L}$ & 131 & 73 & 18 & 5 & 1 & 34 & 4410 & $1589(36 \%)$ \\
\hline
\end{tabular}


Table 3: Summary of phylogenetic trees from nuclear $s q d 1$, sqd1+matK combined, nuclear $26 \mathrm{~S}$, nuclear $26 \mathrm{~S}+s q d 1$ combined, plastid matK+rbcL combined, $26 \mathrm{~S}+s q d 1+m a t \mathrm{~K}$ combined, $s q d 1+m a t \mathrm{~K}+r b c \mathrm{~L}$ combined and $26 \mathrm{~S}+s q d 1+m a t \mathrm{~K}+r b c \mathrm{~L}$ combined analyses. In the topology column, different topologies are indicated with different numbers in brackets which are (1) for ((LP)(SQ)) and (2) for (((LP)S)Q). In the support column, support values for the MP analyses were left as empty, since no bootstrap analyses were carried for the MP analyses. Clades with less than 50\% BS in the MP analyses were not reported. MP: maximum parsimony, ML: maximum likelihood, BI: Bayesian inference.

\begin{tabular}{|c|c|c|c|c|}
\hline Gene region & Reconstruction method & Outgroups & Topology & Support \\
\hline \multirow[t]{3}{*}{ sqd1+matK } & $\mathrm{MP}$ & 28 & $((\mathrm{LP})(\mathrm{SQ}))(1)$ & \\
\hline & $\mathrm{ML}$ & 28 & $((\mathrm{LP})(\mathrm{SQ}))(1)$ & (LP) $85 \%$ BS; (SQ) 96\% BS \\
\hline & $\mathrm{BI}$ & 28 & $((\mathrm{LP})(\mathrm{SQ}))(1)$ & (LP) $0.99 \mathrm{PP}$; (SQ) 0.95 PP \\
\hline \multirow[t]{3}{*}{$26 S$} & MP & 21 & $\begin{array}{l}\text { Non-monophyletic Fabales but } \\
\text { monophyletic Fabales families }\end{array}$ & \\
\hline & $\mathrm{ML}$ & 21 & $((\mathrm{PS}) \mathrm{L})$ & (PS) 61\% BS; ((PS)L) 57\% BS \\
\hline & $\mathrm{BI}$ & 21 & ((PS)L) & (PS) 0.96 PP; ((PS)L) 1.0 PP \\
\hline \multirow[t]{3}{*}{$26 \mathrm{~S}+s q d 1$} & $\mathrm{MP}$ & 28 & $(((\mathrm{LP}) \mathrm{S}) \mathrm{Q})(2)$ & \\
\hline & $\mathrm{ML}$ & 28 & ((LP)SQ) & (LP) 68\% BS; ((LP)SQ) 71\% BS \\
\hline & $\mathrm{BI}$ & 28 & ((LP)SQ) & (LP) 0.98 PP; ((LP)SQ) 1.0 PP \\
\hline \multirow[t]{3}{*}{$26 \mathrm{~S}+s q d 1+$ matK } & MP & 34 & $((\mathrm{LP})(\mathrm{SQ}))(1)$ & \\
\hline & $\mathrm{ML}$ & 34 & $((\mathrm{LP})(\mathrm{SQ}))(1)$ & (LP) $87 \%$ BS; (SQ) 94\% BS \\
\hline & $\mathrm{BI}$ & 34 & $((\mathrm{LP})(\mathrm{SQ}))(1)$ & (LP) 0.99 PP; (SQ) 0.89 PP \\
\hline \multirow[t]{3}{*}{$m a t \mathrm{~K}+r b c \mathrm{~L}$} & MP & 34 & ((LP)(SQ)) (1) & \\
\hline & $\mathrm{ML}$ & 34 & $((\mathrm{LP})(\mathrm{SQ}))(1)$ & (LP) $60 \%$ BS; (SQ) 85\% BS \\
\hline & $\mathrm{BI}$ & 34 & $((\mathrm{LP})(\mathrm{SQ}))(1)$ & (LP) 0.64 PP; (SQ) 0.70 PP \\
\hline \multirow[t]{3}{*}{$s q d 1+m a t \mathrm{~K}+r b c \mathrm{~L}$} & MP & 34 & $((\mathrm{LP})(\mathrm{SQ}))(1)$ & \\
\hline & $\mathrm{ML}$ & 34 & $((\mathrm{LP})(\mathrm{SQ}))(1)$ & (LP) $90 \% \mathrm{BS} ;$ (SQ) $87 \% \mathrm{BS}$ \\
\hline & $\mathrm{BI}$ & 34 & $((\mathrm{LP})(\mathrm{SQ}))(1)$ & (LP) $1.00 \mathrm{PP}$; (SQ) $0.85 \mathrm{PP}$ \\
\hline \multirow[t]{3}{*}{$26 \mathrm{~S}+s q d 1+m a t \mathrm{~K}+r b c \mathrm{~L}$} & $\mathrm{MP}$ & 34 & $((\mathrm{LP})(\mathrm{SQ}))(1)$ & \\
\hline & $\mathrm{ML}$ & 34 & $((\mathrm{LP})(\mathrm{SQ}))(1)$ & (LP) $90 \% \mathrm{BS} ;(\mathrm{SQ}) 88 \% \mathrm{BS}$ \\
\hline & $\mathrm{BI}$ & 34 & $((\mathrm{LP})(\mathrm{SQ}))(1)$ & (LP) $93 \mathrm{PP}$; (SQ) $94 \mathrm{PP}$ \\
\hline
\end{tabular}


Table 4: Comparison of analyses with $26 \mathrm{~S}$ molecular data included/excluded, with/without matK and with/without $r b c \mathrm{~L}$. Results of only the ML analyses are shown.

\begin{tabular}{|c|c|}
\hline \multicolumn{2}{|c|}{ With and without $26 \mathrm{~S}$} \\
\hline sqd1+matK+rbcL: (LP) 90\%; (SQ) 87\% & $26 \mathrm{~S}+s q d 1+m a t \mathrm{~K}+r b c \mathrm{~L}:(\mathrm{LP}) 90 \% ;(\mathrm{SQ}) 88 \%$ \\
\hline sqd1: (LP) $83 \%$ & sqd1+matK: (LP) 85\%, (QS) 96\% \\
\hline 26S+sqd1: (LP) 68\%, (QS) 71\% & 26S+sqd1+matK: (LP) 87\%, (QS) 94\% \\
\hline sqd1+matK: (LP) 85\%, (QS) 96\% & sqd1+matK+rbcL: (LP) 90\%, (QS) 87\% \\
\hline 26S+sqd1+matK: (LP) 87\%, (QS) 94\% & 26S+sqd1+matK+rbcL: (LP) 90\%, (QS) 88\% \\
\hline
\end{tabular}


Table 5: Topology test for the phylogenetic relationships of the four Fabales families. Two different topologies that emerged from our MP, ML and BI analyses are indicated with different numbers in brackets which are (1) for ((LP)(SQ)) and (2) for (((LP)S)Q) ( $p$-value $<0.05$ indicates statistical rejection).

\begin{tabular}{|l|l|l|}
\hline Topology & $\Delta \ln \mathrm{L}$ & AU test $p$-values \\
\hline$(\mathrm{LP})(\mathrm{QS})(1)$ & 0 & 0.731 \\
\hline$(\mathrm{QS}) \mathrm{P}) \mathrm{L}$ & 10.345 & 0.553 \\
\hline$(\mathrm{QS}) \mathrm{L}) \mathrm{P}$ & 10.618 & 0.496 \\
\hline$(\mathrm{SL}) \mathrm{Q}) \mathrm{P}$ & 18.374 & 0.323 \\
\hline$(\mathrm{LP}) \mathrm{Q}) \mathrm{S}$ & 26.899 & 0.226 \\
\hline$(\mathrm{LP}) \mathrm{S}) \mathrm{Q}(2)$ & 31.992 & 0.176 \\
\hline$(\mathrm{PS}) \mathrm{L}) \mathrm{Q}$ & 50.629 & 0.0675 \\
\hline
\end{tabular}

\section{APPENDIX}

Appendix 1: Taxon sampling for the phylogenetic analyses of order Fabales based on the nuclear sqd 1 and $26 \mathrm{~S}$ rDNA, and the plastid $r b c \mathrm{~L}$ and matK. A dash indicates the region was not sampled. Information is presented in the following order: taxon name, voucher specimen of the samples worked in this study (SOURCE); GenBank accessions: sqd1, 26S, matK, rbcL.

Leguminosae. Subfamily Duparquetioideae: Duparquetia orchidacea Baill. Bruneau 1098 (K); MG431081, MG431186, EU361937.1, - . Subfamily Cercidoideae: Adenolobus garipensis (E. Mey.) Torre \& Hillc. Leistuer et al. 246 (K); -, MG431188, EU361844.1, AM234268.1. A. pechuelli (Kuntze) Torre\& Hillc. Oliver et al. 6527; MG431096, MG431178, JN881353.1, - . Bauhinia syringifolia (F. Muell.) Wunderlin Weston 2449 (NSW); -, MG431187, -, AM234267.1. B. galpinii N. E. Br. Forest 347 (NBG); MG431094, MG431172, JN881366.1, AM234262.1. Brenierea insignis Humbert Dupuy M430 (K); -, MG431166, EU361889.1, AM234269.1. Cercis canadensis L. JBM 1397-91; MG431097, MG431189, EU361912.1, U74188.1. Griffonia physocarpa Baill. Cheek 8013 (K); MG431095, MG431190, EU361961.1, AM234265.1. Subfamily Dialioideae: Dialium guianensis (Aubl.) Sandw. Klitgaard 686 (K); MG431086, -, EU361930.1, AM234245.1. Poeppigia procera Presl. Howard 5162 (MT); MG431087, -, EU362026.1, AM234246.1. Storckiella australiensis J. H. Ross \& B. Hyland Hill et al. 2096 (K); - , -, GU321970.1, AM234249.1. Zenia insignis Chun Manos 1418 (DUKE); - , -, EU362065.1, AF308722.1. Subfamily Detarioideae: Afzelia bella Harms. Breteler.13120; MG431085, -, EU361846.1, KC628648.1. Amherstia nobilis Wall. Baker 490 (KEP); MG431084, MG431182, EU361849.1, AM234234.1. Anthonotha macrophylla P. Beauv. Wieringa 2996 (WAG); MG431083, MG431205, EU361853.1, KC628430.1. A. pynaertii (De Wild.) Exell \& Hillc. Breteler 12781 (WAG); MG431063, -, EU361854.1, - . Aphanocalyx cynometroides Oliver Wieringa 2355 (WAG); -, MG431179, -, AM234241.1. A. djumaensis (De Wild.) J.Leonard; -, -, EU361856.1, -. A. margininervatus J. Leonard Breteler 12346 (WAG); MG431082, - , - - - Brownea sp. Pérez, A. \& Alvia, P. 38917 QCA (K); MG431069, -, AY386932.1, U74186.1. Browneopsis ucayalina Huber Klitgaard 684 (K); MG431089, MG431185, EU361894.1, AM234233.1. Crudia gabonensis Harms Wieringa 2585 (WAG); -, MG431167, EU361922.1, AM234230.1. Cynometra crassifolia Benth.; -, 
-, KF294055.1, -. C. mannii Oliv. Bruneau 1364; MG431062, MG431177, -, AM234231.1.

Detarium macrocarpum Harms. Breteler 12528 (WAG); -, MG431195, GU321969.1, AM234239.1. Goniorrhachis marginata Taub. 3585 Cara 5338 Lewis and Klitgaard; MG431136, MG431183, - , - . Hymenostegia klainei Pellegr. Wieringa 2575 (WAG); MG431061, -, -, KC628501.1. H. robusta Wieringa \& Mackinder; -, -, EU361976.1, - Intsia bijuga (Colebr.) Kuntze; -, -, EU361981.1, KF496786.1. Intsia sp. Colector.4202; MG431060, -, -, - Isoberlinia scheffleri (Harms) Greenway Herendeen 16-XII-97-2 (US); -, MG431169, EU361983.1, AM234240.1. Macrolobium acaciifolium (Benth.) Benth.; -, -, -, U74191.1. M. archeri Cowan Klitgaard 683; MG431059, -, -, - . M. bifolium (Aubl.) Pers.; -, -, EU361996.1, - . Saraca declinata (Jack) Miq. Manos 1417 (DUKE); MG431080, -, EU362033.1, JX856761.1. Tamarindus indica L. JBM 2138-76 (MT); MG431088, MG431184, EU362056.1, AB378732.1. Subfamily Caesalpinioideae: Acrocarpus fraxinifolius Arn. Manos 1416 (DUKE); -, MG431154, GU321971.1, AY904371.1. Archidendron hirsutum I. Nielsen Douglas 625 (MEL); MG431110, MG431157, EU361860.1, AM234253.1. Caesalpinia decapetala (Roth) Alson Herendeen and Mbago 19-XII-97-1 (US); KF379299.1, -, KF379248.1, -. C. pulcherrima (L.) Sw; KF379321.1, -, EU361906.1, U74190.1. Calliandra juzepczukii Standl.; -, -, EU812019.1, -. C. trinervia Benth. Klitgaard 622 (K); MG431072, MG431160, -, -. Calpocalyx dinklagei Harms. Breteler 15461 (WAG); MG431107, MG431155, EU361907.1, AM234257.1. Cassia grandis L. f. Smith 2061 (MT); MG431065, -, -, -. Cedrelinga cateniformis (Ducke) Ducke Pennington, T.D., Daza, A. \& Muellner, A. 17761 MOL (K) (sqd1)/ Klitgaard 698 (K) (26S); MG431074, MG431159, AF521818.1, AM234256.1. Ceratonia siliqua L. Wieringa 3341 (WAG); -, MG431194, AY386852.1, U74203.1. Chamaecrista fasciculata (Michx.) Greene; -, -, AY386955.1, U74187.1. C. nictitans (L.) Moench var. jaliscensis (Greenman) Irwin \&Barnaby Klitgaard 654; MG431098, MG431181, -, - . Colvillea racemosa Bojer; KF379329.1, -, EU361916.1, AY904425.1. Conzattia multiflora Standl.; KF379326.1, -, AY386918.2, AY904416.1. Delonix boiviniana (Baill.) Capuron Bruneau 1365 (MT); KF379330.1, -, KF379239.1, - D. floribunda (Baill.) Capuron Bruneau 1393 (MT); KF379331.1, -, KF379240.1, AY904421.1. D. pumila Du Puy, Phillipson \& R. Rabev. Bruneau 1411 (MT); KF379328.1, -, KF379237.1, AY904424.1. D. regia (Boj. ex Hook.) Raf; KF379327.1, 一, KF379238.1, AY904419.1. D. velutina Capuron Bruneau 1354 (MT); KF379324.1, -, KF379236.1, AY904423.1. Denisophytum madagascariense R. Vig.; KF379301.1, -, KF379246.1, - . Erythrostemon calycinus (Benth.) L. P. Queiroz Lewis 1885 (K); -, MG431176, -, - . E. ivorense A. Chev. Breteler 15446 (WAG); MG431092, -, EU361948.1, U74205.1. Gleditsia sinensis Lam. Haston V200305; - , - , - AY904374.1. G. triacanthos L. JBM 2327-82 (sqd1)/ JBM 2674-95 (MT) (26S); MG431093, MG431173, EU361958.1, - . Guilandina bonduc L.; KF379298.1, -, KF379242.1, —. Gymnocladus dioica (L.) Koch JBM 1830-72 (sqd1)/ JBM 2099-88 (MT) (26S); MG431066, MG431174, EU361966.1, U74193.1. Inga edulis Mart. ; - , - EU361980.1, - . I. nouragensis Poncy; -, -, -, JQ626021.1. Inga sp. Klitgaard 677 (K); MG431075, MG431193, -, -. Mezoneuron scortechinii F. Muell. Wieringa 4195 (WAG); MG431134, -, -, - . Mimosa colombiana Britton \& Killip Torres, A.M. 21343 (K); MG431073, -, DQ790603.1, -. M. pudica L.; -, -, -, KJ008941.1. Moullava digyna (Rottl.) E. Gagnon \& G. P. Lewis, comb. nov. Lewis 2067 (K); MG431135, -, EU361902.1, Parkia multijuga Benth. Klitgaard 697 (K); MG431109, MG431161, EU362018.1, AM234251.1. Parkinsonia aculeata L. Spellenberg \& Brouillet 12704 (MT); KF379325.1, MG431168, -, -. P. raimondoi Brenan; - , - - , AY904413.1. P. florida (Benth. ex A. Gray) S. Watson; - , , AY386856.2, - . Pentaclethra macroloba (Willd.) Kuntze Boyle, B. et al. 6720 (K) (sqd1)/ DeWilde 11496 (WAG) (26S); MG431108, MG431156, AY386904.1, - . P. macrophylla Benth.; -, 一, -, AM234250.1. Poincianella palmeri (S. Watson) E. Gagnon \& G. P. Lewis, comb. nov. Lewis et al. 2065 (K); MG431133, -, -, -. Pterogyne nitens Tul. Herendeen 13- XII-97-1 (US); MG431090, MG431171, EU362031.1, AY904377.1. Senna alata (L.) Roxb. Bruneau 1076 (K); MG431064, MG431180, EU362042.1, U74250.1. Tara spinosa (Molina) Britton \& Rose; KF379323.1, 一, - , Umtiza listerina T. Sim Schrire 2602 (K); MG431091, MG431175, EU362062.1, AM234237.1. Vachellia caven (Molina) Seigler \& Ebinger JBM 386-89 (MT); -, MG431191, AF274131.1, Z70145.1. Zapoteca tetragona (Willd.) H.M. Hern. Klitgaard 649 (K); -, MG431158, AF523097.1, JQ592095.1. 
Subfamily Papilionoideae: Arachis hypogaea L.; FJ824608.1, -, EU307349, U74247.1. Astragalus laxmannii var. robustior (Hook.) Barneby \& S.L. Welsh; -, -, -, JX848460.1. A. Iusitanicus Lam. Edmondson, J.R. \& McClintock, M.A.S. 2803 (K); MG431068, -, -, - . A. mongholicus Bunge; -, -, EF685993.1, - . Baphia nitida Afzel. ex Lodd. Bruneau sn. LBG; MG431103, MG431162, EU361867.1, AM234261.1. Bobgunnia fistuloides (Harms) J.H. Kirkbr. \& Wiersema Breteler 14870 (WAG); MG431071, MG431165, EU361885.1, AM234258.1. Cadia purpurea (G.Piccioli) Aiton; -, 一, JX295932.1, U74192.1. C. pubescens Bojer ex Baker Dorr, L.J., Barnett, L.C. \& Brooks, R. 3279 (K); MG431104, -, -, -. Cladrastis kentukea (Dum.Cours.) Rudd; -, -, AF142694.1, -. C. sinensis Hemsl. Punethalengam, E. s.n. (K); MG431105, -, -, Z95551.1. Dalbergia congestiflora Pittier; -, -, AF142696.1, - D. hupeana Hance; -, -, -, U74236.1. D. yunnanensis Franch. Sino-British Exp. to Cangshan 1981 (K); MG431099, -, -, -. Exostyles venusta Spreng. Klitgaard 24 (K); MG431067, -, JX152591.1, - . Lecointea peruviana J. F. Macbr. Klitgaard B. B. 679 (K); MG431106, MG431163, JX295927.1, AM234260.1. Lotus corniculatus L. Cowan. R.S. MFF128 (K); MG431100, 一, HM049505.1, U74213.1. Sclerolobium sp. Klitgaard 687 (K); -, MG431170, AM234242.1, 一. Lupinus luteus L. ABH 31123 (ABH); MG431101, -, HM851129.1, HM850145.1. Sophora chrysophylla (Salisb.) Seem. -, GU256432.1, -, - . S. microphylla Aiton N. A. Smith (AK); MG431070, -, -, - Swartzia cadiosperma Spruce ex. Benth. Klitgaard 664 (K); MG431102, MG431164, EU362053.1, AM234259.1. Wisteria sinensis (Sims) DC.; FN675910.1, —, AF142732.1, Z95544.1. Polygalaceae: Tribe Xanthophylleae: Xanthophyllum octandrum Domin Forster 9554 (NY); -, MG431137, -, AM234229.1. Xanthophyllum sp. Coode 7760 (K); MG431076, 一, EU604044.1, - . Tribe Carpolobieae: Atroxima afzeliana (Oliv. ex Chodat) Stapf Jongkind 4281 (WAG); -, MG431150, EU604049.1, AM234175.1. Carpolobia alba G. Don. Cable 747 (K); MG431114, MG431145, EU604053.1, AM234176.1. Tribe Moutabea: Eriandra fragrans P. Royen \& Steenis R Pullen 7234 (K); MG431115, MG431146, EU604051.1, AM234170.1. Moutabea aculeata (Ruiz \& Pav.) Poepp. \& Endl. Smith 1522 (US); -, MG431149, -, AM234169.1. M. guianensis Aubl.; -, -, JQ626362.1, - . Tribe Polygaleae: Bredemeyera colletioides (Phil.) Chodat Guaglianone et al. 1587 (NY); -, MG431148, -, AM234171.1. B. floribunda Willd. Bello 742 (COL) (sqd1)/ Irwin et al. 27995 (NY) (26S); MG431113, MG431147, EU596520.1, EU644699.1. Comesperma esulifolium (Gand.) Telford 12350 (CANB); -, MG431192, EU596516.1, AM234179.1. Monnina xalapensis Kunth Chase 963 (K); -, MG431151, EU604047.1, AM234184.1. Muraltia alba Levyns Goldblatt 9515 (MO); -, MG431144, -, - . M. heisteria (L.) DC. -, -, -, AJ829698.1. M. spinosa (L.) Dumort Chase $281(\mathrm{~K})$; -, MG431152, -, - . M. thunbergii Eckl. \& Zeyh. Forest 250 (K, NBG); MG431111, -, AM889730.1, - . Polygala acuminata Willd. Wurdack 1818 (NY); -, MG431141, 一, AM234195.1. P. alpicola Rupr. Chase 11747 (K); -, MG431139, EU604041.1, AM234191.1. P. californica Nutt.; -, -, AY386842.1, -. P. chamaebuxus (L.) var. grandiflora Chase 11323 (K); -, MG431142, -, -. P. cowellii (Britton) S.F. Blake; -, -, -, AM234199.1. P. ligustrioides A. St. Hil. Harley et al. 20751 (K); -, MG431143, -, AM234202.1. P. senega L. Brouillet 99-11 (MT); -, MG431138, -, -. Polygala sp. Bello 48; MG431112, -, -, -. P. vulgaris L. Fay 316 (K); -, MG431140, EU604046.1, AM234193.1. Securidaca diversifolia (L.) S.F. Blake Chase 2998 (MICH); -, -, JQ588837.1, AM234225.1. Surianaceae: Cadellia pentastylis F. Muell. Thompson \& Robin sn (K); MG431116, MG431196, EU604056.1, L29491.1. Guilfoylia monostylis (Benth.) F. Muell. Fernando \& Wannan sn (UNSW 21246); -, MG431203, EU604031.1, L29494.1. Recchia mexicana Moc. \& Sessé ex DC. No voucher (see Forest, 2004); -, MG431153, EU604045.1, AM234270.1. Suriana maritima L.; -, -, AY386950.1, U07680.1. Stylobasium spathulatum Desf. Latz. 13213 (K); MG431117, MG431204, EU604032.1, U06828.1. Quillajaceae: Quillaja saponaria Molina Chase, M.W. 10931 (K) (sqd1)/ Morgan 2146 (WS) (26S); MG431077, -, AY386843.1, U06822.1. Outgroups. Zygophyllales: Krameria ixine Lofling. Fernandez 22529 (COK); MG431078, -, EU604050.1, EU644679.1. $\boldsymbol{K}$. Ianceolata Torr. Chase 103 (MICH); -, MG431198, -, - . Zygophyllum rosowii Bunge D1507; -, , JF956824.1, JF944812.1. Z. xanthoxylum (Bunge) Maxim. Chase 1700 (K); -, MG431197, -, -. Celastrales: Celastrus orbiculatus Thunb. Chase, M.W. 2274 (K); MG431079, AF222357.1, EF135517.1, AY788194.1. Oxalidales: Eucryphia lucida (Labill.) Baill.; —, AF036494.1, —, —. 
Malpighiales: Licania alba (Bernoulli) Cuatrec.; -, KJ414473.1, -, -. Viola suavis M. Bieb.; AM503808.1, -, -, - . V. chaerophylloides (Regel) W. Becker; -, -, JQ950581.1, JQ950611.1. Rosales: Colubrina arborescens (Mill.) Sarg. Christenhusz, M.J.M. 5714; MG431131, -, -, - . C. asiatica (L.) Brongn.; -, DQ146521.1, - , - Elaeagnus commutata Bernh. ex Rydb.; - , - , , JX848456.1. Elaeagnus sp. Chase, M.W. 2414 (K); MG431130, AF479235.1, -, - . E. umbellata Thunb.; -, -, AY257529.1, - . Ficus sp. Moore 315; - , - , - EU002278.1. F. benjamina L.; FN675916.1, - , JQ773509.1, - . F. tikoua Bureau; -, JF317386.1, -, - . Fragaria $\times$ ananassa (Weston) Duchesne; -, X58118, -, U06805.1. Fragaria vesca L.; XM_004290997.1, -, AF288102.1, -. Hippophae rhamnoides L. Crawley, M.J. MJC150; MG431129, JF317389.1, JF317428.1, JF317488.1. Humulus lupulus L. Fay, M.F. MFF341 (K); MG431128, AY686777.1, AY257528.1, AF206777.1. Gironniera sp. Puradyatmika 10455 (BO, MAN, FRE, K, L, CANB, A, SING, BRI, BISH); MG431132, -, -, -. G. subaequalis Planch.; -, -, AF345319.1, AF500340.1. Malus domestica Borkh. ; XM_008395413.1, -, AM042561.1, - . M. spectabilis (Aiton) Borkh. ; -, -, 一, JQ391363.1. Prunus armeniaca L.; FN675931.1, -, HQ235101.1, KF154869.1. P. avium (L.) L.; FN675932.1, - , AM503828.1, HQ235394.1. P. cerasus L.; FN675933.1, -, FJ899111.1, HQ235416.1. P. domestica L.; FN675934.1, —, FJ899110.1, L01947.2. P. persica (L.) Stokes; FN675912.1, AY935820.1, AF288117.1, AF411493.1. Shepherdia argentea (Pursh) Nutt. Chase 3176 (K); -, MG431201, -, AJ225787.1. S. canadensis (L.) Nutt.; -, -, KC475874.1, -. Fagales: Alnus glutinosa (L.) Gaertn; -, AF479106, KF419025.1, EU644678.1. Betula pendula Roth AM503778.1, 一, AY372014.1, KF418943.1. Casuarina equisetifolia L. Edwards, P.J. 4011 (K); MG431119, -, AY033837.1, AY033859.1. Juglans nigra L.; -, AF479105.1, -, U00437.1. J. regia L. Fay, M.F. et al. MFF416 (K); MG431118, -, AF118038.1, -. Morella cerifera (L.) Small; -, AF479247.1, -, -. M. nana (A. Chev.) J. Herb.; -, -, KF419020.1, - . M. quercifolia (L.) Killick Fay, M.F. s.n. (K); MG431120, -, -, -. M. rubra Lour; -, -, -, KF418924.1. Myrica gale L. Fay, M.F. MFF 238 (K); MG431123, -, AY191715.1, AJ626757.1. Nothofagus alpina (Poepp. \& Endl.) Oerst.; -, 一, 一, L13342.2. N. antarctica (G.Forst.) Oerst.; -, -, AY263924.1, - . N. obliqua (Mirb.) Oerst. Chase, M.W. 33143, (K) (1000 Plant Genomes Project); MG431121, -, -, - . Platycarya strobilacea Siebold \& Zucc. Herbarium Kewense Cultivated Plants s.n. (K); MG431122, —, AY147100.1, AY263933.1. Ticodendron incognitum Gómez-Laur. \& L.D. Gómez Brummitt, R.K. \& Aizprua, R. 21139 (K); MG431124, -, U92855.1, AF061197.1. Trigonobalanus verticillata Forman Chase 595 (K); -, MG431202, AB084771.1, AB084768.1. Cucurbitales: Abobra tenuifolia (Gillies ex Hook. \& Arn.) Cogn. Chase 915 (K); -, MG431200, DQ536629.1, AF008961.1. Begonia glabra Aubl. Chase 945 (K); -, MG431199, -, -. B. ulmifolia Willd.; -, -, GU397115.1, -. B. metallica W.G.Sm. x Begonia sanguinea Raddi; -, -, -, L12670.1. Bolbostemma paniculatum (Maxim.) Franquet TCMK 854 (K); MG431125, -, DQ469139.1, DQ501255.1. Corynocarpus laevigatus J.R. Forst. \& G. Forst. Chase, M.W. 236 (NCU); MG431126, AF479110.1, AY968448.1, AF148994.1. Cucumis sativus L.; XM_004167788.1, 一, DQ536662.1, L21937.1. Datisca cannabina L. Chase, M.W. 2745; MG431127, AY968410.1, AB016467.1, L21939.1. 
Figure 1. Maximum likelihood tree of $26 \mathrm{~S}+s q d 1+m a t \mathrm{~K}+r b c \mathrm{~L}$ analysis. Outgroup taxa, Polygalaceae, Surianaceae, Quillajaceae and Leguminosae with six subfamilies (Cercidoideae, Detarioideae, Duparquetioideae, Dialioideae, Caesalpinioideae and Papilionoideae) are indicated. Bootstrap values are indicated below branches. 